\title{
Influence of Different Nutrient Concentration on Strawberry under Hydroponic Cultivation System
}

\author{
Vikas $^{1}$, Anjil Kumar², Arun Kumar ${ }^{2 *}$, Anshu Singh², Praveen Kumar², \\ Jaihoon Rafie ${ }^{2}$, Parkash Verma ${ }^{2}$ and Ajay Kumar ${ }^{2}$ \\ ${ }^{1}$ School of Agriculture, Lovely Professional University, Phagwara-144411, Punjab, India \\ ${ }^{2}$ School of Agriculture, Roorkee college of Engineering, Roorkee, 247667, Uttarakhand, India \\ *Corresponding author
}

\begin{tabular}{|c|c|}
\hline & A B S T R A C T \\
\hline Keywords & \multirow{5}{*}{$\begin{array}{l}\text { The present investigation entitled 'Influence of different nutrient concentration on } \\
\text { strawberry under hydroponic cultivation system'was carried out during } 2016 \text { to } \\
2017 \text { at agriculture field of School of Agriculture, Lovely Professional University, } \\
\text { Punjab. In this research takes the seven treatments in hydroponic system. The } \\
\text { experiment is carried out in wooden box block design structureand to evaluate the } \\
\text { higher success in terms of plant height, plant stem girth, number of leaves/plant, } \\
\text { leaf area, number of branches/plant, number of flowers/plant, number of } \\
\text { fruits/plant, yield/plant and harvesting index. The maximum plant height and } \\
\text { number of fruits/plant was noted in } \mathrm{T}_{5} \text { at } 90 \text { days. And maximum stem girth, leaf } \\
\text { area, number of branches/plant noted inT } \mathrm{T}_{7} \text { at } 75 \text { days while the maximum number } \\
\text { of leaves and yield/plant recorded in } \mathrm{T}_{6} \text { at } 90 \text { days. }\end{array}$} \\
\hline Strawberry, & \\
\hline $\begin{array}{l}\text { Hydroponic, } \\
\text { Wooden box block } \\
\text { design, Structure. }\end{array}$ & \\
\hline Article Info & \\
\hline $\begin{array}{l}\text { Accepted: } \\
\text { 26 September } 2017 \\
\text { Available Online: } \\
\text { 10 October } 2017\end{array}$ & \\
\hline
\end{tabular}

\section{Introduction}

Strawberry (Fragaria $x$ ananassa) is the popular soft fruit and mainly grows in subtropical. Now a day, the production of strawberry is goes down due to many climatic condition like more temperature and less agronomical practices. It needs more care and management as compare to the other crops. And it cultivated mainly in controlled environment, but that control environment having more cost of cultivation. The farmer also having less land for taking crops. So that in modern world new technique of cultivation is developed which is called hydroponics system it help in to increase the yield and good growth of crops. Hydroponic system is the stared in 1627 but discussed earlier in a book of Syva Sylvarum by Francis Bacon. And John Woodward published an experiment with spearmint. And found that the spearmint is grown better on the water as compare to other soil culture (Douglas et al., 1975). Hydroponic is the cultivation of crop without soil environment. In hydroponic mainly using different type of media or nutrient solution for growing crops. And keep the root of the plant in the solution of nutrient. Mainly vermiculite, cocopeat, bark of plant, perlite, and rock wool are used. And hydroponic is many types like wick system, flood and drain system, drip system and N.F.T system (Nutrients Film Techniques). On the other hand, every kind of nutrients is 
used in this system. One advantage is the soil born disease of strawberry is totally end. But this is for that type of farmer they are not having much land for cultivation. So this hydroponic system is best for marginal farmer. In India new reached is worked on that system because it produces good quality of crop and production. It reduces the disease of crops those which are disseminated by the soil and also reduce the rotting of strawberry fruits. But this system shows the good result in quality of strawberry and other growth parameter. Now due to increase of demand has caused emphasis on modern strawberry producing systems such as without soil cultivation or hydroponic system to replace the old and traditional systems of cultivation. Hydroponic required more care as compare to field crops. Like checking of $\mathrm{pH}, \mathrm{EC}$ and concentration of nutrients during crop duration. This system is also good for terrace farming in home for kitchen farming. And for the small farmer, it is best method of taking more income.

\section{Materials and Methods}

\section{Location of research}

It is carried out at Experimental Farm of School of Agriculture, Lovely Professional University, Phagwara, Punjab. The experiment shall be laid out on pot with three replications. The package of practices for raising the crop shall be followed as per latest Punjab Agriculture University guidelines and check the Nitrogen, Phosphorus, Potassium and organic carbon of soil. And hydroponic nutrients solution used in NFT structure.

\section{Observation details}

For the determination of the plants growth\& fruit quantity selected various parameters viz; plant height $(\mathrm{cm})$, plant girth $(\mathrm{mm})$, number of leaves/plant,leaf area $\left(\mathrm{cm}^{2}\right)$, number of branches/plant, number of flowers/plant, number of fruits/plant, yield/plant and harvesting index.

\section{Statistical analysis}

The data collected during the course of investigation were subjected to statistical analysis by adopting appropriate method of analysis of variance as described by Fisher. The critical difference for the treatment comparison was worked out, wherever the SPSS 16 is used to analysis the data.

\section{Results and Discussion}

The plant height, stem girth, number of leaves/plant, leaf area and number of branches/plant noted at 15, 30, 45, 60, 75 and 90 days after transplanting (Tables 1-5). And number of flowers/plant, number of fruits/plant was observed at 45, 60, 75 and 90 days after transplanting while Yield/Plant, Harvesting Index recorded at 90 days after transplanting (Tables 6-9).

At 15 days the plant height was noted maximum $(5.03 \mathrm{~cm})$ and minimum $(4.03 \mathrm{~cm})$. And at 60 days the plant height increase $18.94 \%$ as compared to the 45 days; however the variation is from $5.86-7.23 \mathrm{~cm}$ and the $\mathrm{T}_{5}$ (25\%RDF $+75 \%$ Vermicompost) shows the best impact on the plant height. Some researcher ( Patil et al., 2013) showed that the different type of mulching colour played a great role in the plant height. Black polythene mulching shows the $24.03 \mathrm{~cm}$ and white polythene shows the $22.4 \mathrm{~cm}$ height of plants. The GA 3975 ppm shows the best growth in plant height $(46.10 \mathrm{~cm})$ in strawberry plant (Rakeshkumar et al., 2013). The plant height is depends on the dose of nitrogen also like $100 \mathrm{~kg} \mathrm{~N} / \mathrm{ha}+80 \mathrm{~kg} \mathrm{~K} / \mathrm{ha}$ treatment shows the best plant height 14.30-18.16cm (Gowhar A. Dar et al., 2013). At 15 days, 46.15\% increase stem girth in between the treatment; 
at 30 days, $52.94 \%$ increase; at 45 days, $42.85 \%$ increase in stem girth; at 60 days $31.81 \%$ increase in stem girth; At 75 days $33.33 \%$ increase in the stem girth respectively. At 30days stem girth observation show $23.52 \%$ increase as compared to stem girth of 15days; however the variation in treatment are from $0.08-0.17$ $\mathrm{mm}$ and treatment $\mathrm{T}_{6}(30 \%$ sewage sludge $+70 \%$ cocopeat) shows best impact on stem girth. The changing in the growth of strawberry depends on the organic manure like poultry manure shows the best impact on the growth parameter due to its height nutrient availability (Kirad et al., 2009).

At 45days, stem girth observation shows $23.80 \%$ increase in stem girth as compared to stem girth of 30days; however the variation in treatment are from $0.12-0.21 \mathrm{~mm}$ and treatment $\mathrm{T}_{5} \quad(20 \%$ sewage sludge $+80 \%$ cocopeat) shows the best impact on stem girth. Different types of substrate influence in the growth of strawberry plant like cocpeat + perlite show the best impact on the plant height, stem girth, fruits weight etc. (Razieh Ebrahimi et al., 2012). At 60days the result shows that $13.63 \%$ increase in stem girth as compared to the 45 days; however the variation in treatment from $0.15-0.22 \mathrm{~mm}$ and treatment $\mathrm{T}_{5} \quad$ (20\%sewage sludge $+80 \%$ cocopeat), $\mathrm{T}_{6}$ (30\% sewage sludge $+70 \%$ cocopeat), and $\mathrm{T}_{7}$ (control) shows best impact on stem girth. At 75 days $33.33 \%$ increase in the stem girth as compared to the 60 days; however the variation in treatments are from $0.18-0.27 \mathrm{~mm}$ and treatment $\mathrm{T}_{7}$ (control) shows best impact on stem girth. And also increase the concentration of the potassium $300 \mathrm{ppm}$ increase the growth habitat of plant (Razieh Ebrahimi et al., 2012).

Table.1 Effect of nutrient concentration on the plant height $(\mathrm{cm})$ of strawberry at 15, 30, 45, 60, 75 and 90 days in hydroponic system

\begin{tabular}{lllllll}
\hline Treatment & PH 15 & PH 30 & PH 45 & PH 60 & PH 75 & PH 90 \\
T1 & $5.03 \mathrm{a} \pm 0.26$ & $5.13 \mathrm{a} \pm 0.21$ & $6.06 \mathrm{a} \pm 0.37$ & $6.23 \mathrm{a} \mathrm{a} \pm 0.29$ & $6.23 \mathrm{a} \mathrm{a} \pm 0.29$ & $6.23 \mathrm{ab} \pm 0.29$ \\
T2 & $4.13 \mathrm{a} \pm 0.14$ & $4.70 \mathrm{a} \pm 0.11$ & $5.73 \mathrm{a} \pm 0.08$ & $5.90 \mathrm{~b} \pm 0.11$ & $5.90 \mathrm{~b} \pm 0.11$ & $5.90 \mathrm{~b} \pm 0.11$ \\
T3 & $4.43 \mathrm{a} \pm 0.49$ & $4.73 \mathrm{a} \pm 0.55$ & $5.70 \mathrm{a} \pm 0.43$ & $5.86 \mathrm{~b} \pm 0.50$ & $5.86 \mathrm{~b} \pm 0.50$ & $5.86 \mathrm{~b} \pm 0.50$ \\
T4 & $4.50 \mathrm{a} \pm 0.70$ & $5.00 \mathrm{a} \pm 0.80$ & $6.00 \mathrm{a} \pm 0.77$ & $6.26 \mathrm{a} \mathrm{a} \pm 0.63$ & $6.26 \mathrm{a} \mathrm{b} \pm 0.63$ & $6.26 \mathrm{ab} \pm 0.63$ \\
T5 & $4.83 \mathrm{a} \pm 0.58$ & $5.46 \mathrm{a} \pm 0.57$ & $6.86 \mathrm{a} \pm 0.26$ & $7.23 \mathrm{a} \pm 0.20$ & $7.23 \mathrm{a} \pm 0.20$ & $7.23 \mathrm{a} \pm 0.20$ \\
T6 & $4.03 \mathrm{a} \pm 0.68$ & $5.36 \mathrm{a} \pm 0.56$ & $6.50 \mathrm{a} \pm .0 .45$ & $6.90 \mathrm{a} \mathrm{b} \pm 0.37$ & $6.90 \mathrm{ab} \pm 0.37$ & $6.90 \mathrm{a} \mathrm{a} \pm 2.37$ \\
T7 & $3.93 \mathrm{a} \pm 0.18$ & $5.26 \mathrm{a} \pm 0.20$ & $6.46 \mathrm{a} \pm 0.21$ & $6.63 \mathrm{a} \mathrm{a} \pm 0.14$ & $6.63 \mathrm{a} \mathrm{a} \pm 0.14$ & $6.63 \mathrm{a} \mathrm{a} \pm 0.14$ \\
\hline
\end{tabular}

PH= Plant Height

Table. 2 Effect of nutrient concentration on the stem girth (mm) of strawberry at 15, 30, 45, 60, 75 and 90 days in hydroponic system

\begin{tabular}{lllllll}
\hline Treatment & SG15 & SG30 & SG45 & SG60 & SG75 & SG90 \\
T1 & $0.08 \mathrm{~b} c \pm 0.01$ & $0.11 \mathrm{a} \pm 0.01$ & $0.14 \mathrm{a} b \pm 0.01$ & $0.16 \mathrm{a} \mathrm{b} \pm 0.02$ & $0.19 \mathrm{c} \pm 0.02$ & $0.20 \mathrm{a} \pm 0.01$ \\
T2 & $0.076 \mathrm{c} \pm 0.01$ & $0.10 \mathrm{~b} \mathrm{c} \pm 0.01$ & $0.14 \mathrm{a} \mathrm{b} \pm 0.01$ & $0.16 \mathrm{a} \mathrm{b} \pm 0.02$ & $0.18 \mathrm{c} \pm 0.02$ & $0.19 \mathrm{a} \pm 0.02$ \\
T3 & $0.10 \mathrm{a} \mathrm{b} \pm 0.00$ & $0.13 \mathrm{a} \mathrm{b} \mathrm{c} \pm 0.01$ & $0.15 \mathrm{a} \mathrm{b} \pm 0.02$ & $0.19 \mathrm{a} \mathrm{b} \pm 0.01$ & $0.21 \mathrm{bc} \pm 0.01$ & $0.22 \mathrm{a} \pm 0.01$ \\
T4 & $0.07 \mathrm{c} \pm 0.00$ & $0.08 \mathrm{c} \pm 0.00$ & $0.12 \mathrm{~b} \pm 0.00$ & $0.15 \mathrm{~b} \pm 0.00$ & $0.18 \mathrm{c} \pm 0.00$ & $0.19 \mathrm{a} \pm 0.00$ \\
T5 & $0.12 \mathrm{a} \mathrm{b} \pm 0.00$ & $0.16 \mathrm{a} \mathrm{b} \pm 0.01$ & $0.21 \mathrm{a} \pm 0.01$ & $0.22 \mathrm{a} \pm 0.01$ & $0.23 \mathrm{abc} \pm 0.01$ & $0.24 \mathrm{a} \pm 0.01$ \\
T6 & $0.13 \mathrm{a} \pm 0.02$ & $0.17 \mathrm{a} \pm 0.03$ & $0.19 \mathrm{a} \mathrm{b} \pm 0.03$ & $0.22 \mathrm{a} \pm 0.01$ & $0.25 \mathrm{ab} \pm 0.01$ & $0.26 \mathrm{a} \pm 0.00$ \\
T7 & $0.11 \mathrm{a} \mathrm{a} \pm 0.01$ & $0.16 \mathrm{a} \mathrm{b} \pm 0.02$ & $0.19 \mathrm{a} \mathrm{b} \pm 0.03$ & $0.22 \mathrm{a} \pm 0.02$ & $0.27 \mathrm{a} \pm 0.02$ & $0.23 \mathrm{a} \pm 0.02$ \\
\hline
\end{tabular}

SG= Stem Girth 
Table.3 Effect of nutrient concentration on the number of leaves/plant of strawberry at 15, 30, 45, 60, 75 and 90 days in hydroponic system

\begin{tabular}{lllllll}
\hline Treatment & LP15 & LP30 & LP45 & LP60 & LP75 & LP90 \\
T1 & $2.66 \mathrm{c} \pm 0.33$ & $4.00 \mathrm{c} \pm 0.57$ & $6.33 \mathrm{~b} \pm 0.66$ & $10 \mathrm{c} \pm 0.57$ & $11.33 \mathrm{ab} \pm 1.20$ & $11.33 \mathrm{~b} \pm 1.20$ \\
T2 & $3.00 \mathrm{c} \pm 0.00$ & $6.00 \mathrm{bc} \pm 0.57$ & $7.00 \mathrm{~b} \pm 1.15$ & $9.66 \mathrm{c} \pm 0.88$ & $8.33 \mathrm{~b} \pm 4.17$ & $11.66 \mathrm{~b} \pm 0.88$ \\
T3 & $4.00 \mathrm{c} \pm 1.00$ & $6.33 \mathrm{bc} \pm 0.88$ & $9.00 \mathrm{~b} \pm 0.57$ & $12 \mathrm{abc} \pm 0.57$ & $13.66 \mathrm{ab} \pm 0.88$ & $13.66 \mathrm{ab} \pm 0.88$ \\
T4 & $3.66 \mathrm{bc} \pm 0.66$ & $5.33 \mathrm{c} \pm 0.88$ & $9.33 \mathrm{~b} \pm 0.88$ & $10 \mathrm{c} \pm 0.57$ & $12 \mathrm{ab} \pm 1.15$ & $12 \mathrm{~b} \pm 1.15$ \\
T5 & $3.00 \mathrm{c} \pm 0.00$ & $5.66 \mathrm{bc} \pm 0.33$ & $8.66 \mathrm{~b} \pm 0.88$ & $10.66 \mathrm{bc} \pm 0.66$ & $11.66 \mathrm{ab} \pm 0.88$ & $11.66 \mathrm{~b} \pm 0.88$ \\
T6 & $6.33 \mathrm{a} \pm 0.33$ & $9.33 \mathrm{a} \pm 1.45$ & $13.33 \mathrm{a} \pm 1.45$ & $14 \mathrm{a} \pm 1.52$ & $15.66 \mathrm{a} \pm 1.20$ & $15.66 \mathrm{a} \pm 1.20$ \\
T7 & $5.33 \mathrm{ab} \pm 0.66$ & $8.33 \mathrm{ab} \pm 0.66$ & $13.00 \mathrm{a} \pm 0.57$ & $13 \mathrm{a} \mathrm{b} \pm 0.57$ & $10.66 \mathrm{ab} \pm 2.84$ & $14 \mathrm{ab} \pm 0.57$ \\
\hline
\end{tabular}

Table.4 Effect of nutrient concentration on the leaf area $\left(\mathrm{cm}^{2}\right)$ of strawberry at 15, 30, 45, 60, 75 and 90 days in hydroponic system

\begin{tabular}{lllllll}
\hline Treatment & LA15 & LA30 & LA45 & LA60 & LA75 & LA90 \\
T1 & $7.93 \mathrm{~b} \pm 1.73$ & $9.80 \mathrm{c} \pm 1.77$ & $15.63 \mathrm{~b} \pm 2.1$ & $13.13 \mathrm{~b} \pm 2.03$ & $20.80 \mathrm{bc} \pm 1.43$ & $19.03 \mathrm{ab} \pm 3.78$ \\
T2 & $9.16 \mathrm{~b} \pm 1.20$ & $16.86 \mathrm{~b} \pm 1.24$ & $17.16 \mathrm{~b} \pm 0.98$ & $26.83 \mathrm{ab} \pm 1.58$ & $13.43 \mathrm{c} \pm 0.38$ & $13.70 \mathrm{~b} \pm 2.21$ \\
T3 & $19.56 \mathrm{a} \mathrm{b} \pm 6.44$ & $22.23 \mathrm{abc} \pm 6.22$ & $26.36 \mathrm{ab} \pm 5.52$ & $13.13 \mathrm{~b} \pm 5.57$ & $23.03 \mathrm{~b} \pm 1.18$ & $23.16 \mathrm{ab} \pm 0.98$ \\
T4 & $21.60 \mathrm{a} \mathrm{b} \pm 5.83$ & $24.73 \mathrm{ab} \pm 5.26$ & $27.16 \mathrm{ab} \pm 4.82$ & $20.10 \mathrm{ab} \pm 2.80$ & $17.66 \mathrm{bc} \pm 4.17$ & $21 \mathrm{ab} \pm 5.02$ \\
T5 & $17.13 \mathrm{a} \mathrm{b} \pm 1.54$ & $19.03 \mathrm{abc} \pm 1.70$ & $20.36 \mathrm{~b} \pm 1.78$ & $15.70 \mathrm{ab} \pm 1.47$ & $17.10 \mathrm{bc} \pm 1.15$ & $17.86 \mathrm{ab} \pm 3.18$ \\
T6 & $28.63 \mathrm{a} \pm 4.94$ & $29.96 \mathrm{a} \pm 4.68$ & $33.50 \mathrm{a} \pm 4.76$ & $24.46 \mathrm{a} \pm 3.57$ & $21.46 \mathrm{bc} \pm 3.54$ & $31.33 \mathrm{a} \pm 9.19$ \\
T7 & $13.46 \mathrm{~b} \pm 2.89$ & $16.43 \mathrm{bc} \pm 2.91$ & $17.53 \mathrm{~b} \pm 3.25$ & $14.40 \mathrm{ab} \pm 3.57$ & $34.86 \mathrm{a} \pm 4.51$ & $20.83 \mathrm{ab} \pm 5.19$ \\
\hline
\end{tabular}

LA= Leaf Area

Table.5 Effect of nutrient concentration on the number of branches/plant of strawberry at 15, 30, 45, 60, 75 and 90 days in hydroponic system

\begin{tabular}{lllllll}
\hline Treatment & NBP15 & NBP30 & NBP45 & NBP60 & NBP75 & NBP90 \\
T1 & $1.33 \mathrm{~b} c \pm 0.33$ & $2.00 \mathrm{~b} \pm 0.00$ & $3.00 \mathrm{a} \mathrm{b} \pm 0.57$ & $3.00 \mathrm{abc} \pm 0.57$ & $3.66 \mathrm{~b} \pm 0.66$ & $3.66 \mathrm{~b} \pm 0.66$ \\
T2 & $1.00 \mathrm{c} \pm 0.00$ & $2.00 \mathrm{c} \pm 0.00$ & $2.33 \mathrm{~b} \pm 0.33$ & $2.66 \mathrm{~b} \pm 0.33$ & $3.33 \mathrm{~b} \pm 0.33$ & $3.33 \mathrm{~b} \pm 0.33$ \\
T3 & $1.33 \mathrm{bc} \pm 0.33$ & $2.33 \mathrm{a} \mathrm{b} \pm 0.33$ & $2.66 \mathrm{~b} \pm 0.33$ & $3.33 \mathrm{abc} \pm 0.33$ & $3.66 \mathrm{~b} \pm 0.33$ & $3.66 \mathrm{~b} \pm 0.33$ \\
T4 & $1.33 \mathrm{bc} \pm 0.33$ & $1.66 \mathrm{~b} \pm 0.33$ & $2.00 \mathrm{~b} \pm 0.00$ & $2.33 \mathrm{c} \pm 0.33$ & $3.00 \mathrm{~b} \pm 0.57$ & $3.00 \mathrm{~b} \pm 0.57$ \\
T5 & $1.66 \mathrm{bc} \pm 0.33$ & $2.00 \mathrm{~b} \pm 0.57$ & $3.00 \mathrm{ab} \pm 0.57$ & $3.33 \mathrm{abc} \pm 0.33$ & $4.33 \mathrm{ab} \pm 0.66$ & $4.33 \mathrm{ab} \pm 0.66$ \\
T6 & $2.66 \mathrm{a} \pm 0.33$ & $3.32 \mathrm{a} \pm 0.33$ & $4.33 \mathrm{a} \pm 0.33$ & $4.33 \mathrm{a} \pm 0.33$ & $5.33 \mathrm{a} \pm 0.33$ & $5.33 \mathrm{a} \pm 0.33$ \\
T7 & $2.00 \mathrm{ab} \pm 0.00$ & $2.66 \mathrm{a} \mathrm{b} \pm 0.33$ & $3.33 \mathrm{ab} \pm 0.66$ & $4.00 \mathrm{ab} \pm 0.57$ & $5.33 \mathrm{a} \pm 0.33$ & $5.33 \mathrm{a} \pm 0.33$ \\
\hline
\end{tabular}

$\mathrm{NBP}=$ Number of Branches/Plant

Table.6 Effect of nutrient concentration on the number of flowers/plant of strawberry at 45, 60,

75 and 90 days in hydroponic system

\begin{tabular}{lllll}
\hline Treatment & NFP45 & NFP60 & NFP75 & NFP90 \\
T1 & $0.33 \mathrm{~b} \pm 0.33$ & $1.66 \mathrm{a} \pm 0.33$ & $1.00 \mathrm{a} \pm 0.57$ & $1.00 \mathrm{a} \pm 0.57$ \\
T2 & $1.00 \mathrm{a} \mathrm{b} \pm 0.00$ & $0.66 \mathrm{a} \pm 0.66$ & $1.00 \mathrm{a} \pm 0.00$ & $1.33 \mathrm{a} \pm 0.33$ \\
T3 & $0.33 \mathrm{~b} \pm 0.33$ & $1.33 \mathrm{a} \pm 0.33$ & $1.30 \mathrm{a} \pm 0.66$ & $1.33 \mathrm{a} \pm 0.33$ \\
T4 & $0.33 \mathrm{~b} \pm 0.33$ & $1.33 \mathrm{a} \pm 0.33$ & $1.66 \mathrm{a} \pm 0.33$ & $2.00 \mathrm{a} \pm 0.00$ \\
T5 & $0.66 \mathrm{a} \mathrm{b} \pm 0.33$ & $1.00 \mathrm{a} \pm 0.57$ & $1.33 \mathrm{a} \pm 0.33$ & $2.00 \mathrm{a} \pm 0.57$ \\
T6 & $0.66 \mathrm{a} \pm 0.33$ & $2.00 \mathrm{a} \pm 0.57$ & $1.66 \mathrm{a} \pm 0.33$ & $1.66 \mathrm{a} \pm 0.33$ \\
T7 & $0.66 \mathrm{ab} \pm 0.33$ & $1.00 \mathrm{a} \pm 0.57$ & $1.33 \mathrm{a} \pm 0.66$ & $1.00 \mathrm{a} \pm 0.66$ \\
\hline
\end{tabular}

$\mathrm{NFP}=$ Number of flowers/plant 
Table.7 Effect of nutrient concentration on the number of fruits/plant of strawberry at 45, 60, 75 and 90 days in hydroponic system

\begin{tabular}{lllll}
\hline Treatment & NFrP45 & NFrP60 & NFrP75 & NFrP90 \\
T1 & $0.66 \mathrm{a} b \pm 0.33$ & $0.66 \mathrm{a} \pm 0.66$ & $0.66 \mathrm{a} \pm 0.33$ & $1.33 \mathrm{~b} \pm 0.33$ \\
T2 & $0.33 \mathrm{a} \mathrm{b} \pm 0.33$ & $1.33 \mathrm{a} \pm 0.33$ & $0.66 \mathrm{a} \pm 0.33$ & $1.66 \mathrm{a} \mathrm{b} \pm 0.33$ \\
T3 & $1.00 \mathrm{a} \pm 0.00$ & $0.33 \mathrm{a} \pm 0.33$ & $1.33 \mathrm{a} \pm 0.33$ & $1.66 \mathrm{a} \mathrm{b} \pm 0.33$ \\
T4 & $0.33 \mathrm{ab} \pm 0.33$ & $1.00 \mathrm{a} \pm 0.00$ & $2.00 \mathrm{a} \pm 0.57$ & $1.66 \mathrm{a} \pm 0.33$ \\
T5 & $0.33 \mathrm{a} \mathrm{b} \pm 0.33$ & $0.66 \mathrm{a} \pm 0.33$ & $1.00 \mathrm{a} \pm 0.57$ & $2.66 \mathrm{a} \pm 0.33$ \\
T6 & $0.66 \mathrm{a} \mathrm{b} \pm 0.33$ & $1.00 \mathrm{a} \pm 0.00$ & $2.00 \mathrm{a} \pm 0.00$ & $2.33 \mathrm{ab} \pm 0.33$ \\
T7 & $0.00 \mathrm{~b} \pm 0.00$ & $0.66 \mathrm{a} \pm 0.33$ & $1.33 \mathrm{a} \pm 0.33$ & $1.33 \mathrm{~b} \pm 0.33$ \\
\hline
\end{tabular}

NFrP= Number of Fruits/Plant

Table.8 Effect of nutrient concentration on the Yield/Plant of strawberry at 90 days in hydroponic system

\begin{tabular}{ll}
\hline Treatment & YP90 \\
T1 & $10.43 \mathrm{c} \pm 2.52$ \\
T2 & $14.70 \mathrm{bc} \pm 1.67$ \\
T3 & $15.50 \mathrm{bc} \pm 0.98$ \\
T4 & $20.83 \mathrm{ab} \pm 3.40$ \\
T5 & $20.16 \mathrm{ab} \pm 1.78$ \\
T6 & $27.83 \mathrm{a} \pm 4.16$ \\
T7 & $11.83 \mathrm{c} \pm 1.28$ \\
\hline & YP= Yield/Plant
\end{tabular}

Table.9 Effect of nutrient concentration on the harvesting index of strawberry at 90 days in hydroponic system

\begin{tabular}{ll}
\hline Treatment & HI90 \\
T1 & $0.46 \mathrm{a} \pm 0.10$ \\
T2 & $0.54 \mathrm{a} \pm 0.01$ \\
T3 & $0.55 \mathrm{a} \pm 0.03$ \\
T4 & $0.55 \mathrm{a} \pm 0.06$ \\
T5 & $0.52 \mathrm{a} \pm 0.01$ \\
T6 & $0.55 \mathrm{a} \pm 0.04$ \\
T7 & $0.48 \mathrm{a} \pm 0.04$ \\
\hline
\end{tabular}

$\mathrm{HI}=$ Harvesting Index

\section{Experimental Details}

\begin{tabular}{|l|}
\hline Period of work: Mid November to march 2017 \\
\hline Treatment: 7 \\
\hline Replication: 3 \\
\hline Total number of plot: $7 \times 3=21$ \\
\hline Design: Wooden box Block design Structure \\
\hline Variety: Chandler \\
\hline Seed rate: Planting seedling \\
\hline Date of transplanting: 3 Nov, 2016 \\
\hline Method of fertilizer application: Nutrient solution (Hoagland) \\
\hline Method and time of irrigation: Twice a week \\
\hline Date of flowering: 18, Nov 2016 \\
\hline Date of Fruiting: 25, Nov 2016 \\
\hline
\end{tabular}




\section{Details of Treatment}

\begin{tabular}{|l|}
\hline $\mathrm{T}_{1}=10 \%$ Tea Extract (Dry) $+90 \%$ Cocopeat \\
\hline $\mathrm{T}_{2}=20 \%$ Tea Extrac (Dry)t $+80 \%$ Cocopeat \\
\hline $\mathrm{T}_{3}=30 \%$ Tea Extract (Dry) $+70 \%$ Cocopeat \\
\hline $\mathrm{T}_{4}=10 \%$ Sewage sludge $+90 \%$ Cocopeat \\
\hline $\mathrm{T}_{5}=20 \%$ Sewage sludge $+80 \%$ Cocopeat \\
\hline $\mathrm{T}_{6}=30 \%$ Sewage sludge $+70 \%$ Cocopeat \\
\hline $\mathrm{T}_{7}=$ Control \\
\hline
\end{tabular}

At 15 days, in between the treatment $57.97 \%$ increase in the leaf/plant; At 30 days $42.87 \%$ increase; At 45 days $52.51 \%$ increase in leaf/plant; At 60 days $28.57 \%$ increase; At 75 days $46.80 \%$ increase; At 90 days $27.65 \%$ increase in leaf/plant respectively. At 30days leaf/plant observation shows $32.15 \%$ increase as compared to leaf/plant at 15days; however the variation is treatment are from 5.33-9.33 and $\mathrm{T}_{6}$ (30\%sewage sludge $+70 \%$ cocopeat) shows best impact on leaf/plant. It depends on the increase the cocopeat perlite ratio increase chlorophyll $\mathrm{a}$ and $\mathrm{b}$ in leaf and shows the best growth of plants. (Masaru Sakamoto et al., 2016). At 45days leaf/plant observation shows $30 \%$ increases as compared to the 30days; however the variation in treatments are from 9-13.33 and treatment $\mathrm{T}_{6}(30 \%$ sewage sludge $+70 \%$ cocopeat) shows the best impact on the leaf/plant. The number of leaves depends on the time of transplanting and the runner tips. If runners will less that number of leaves will also become less in plants (Carine et al., 2010). At 60 days leaf/plant observation shows the $4.78 \%$ increase in the leaf/plant; however the variation in treatment are 10-14 and treatment $\mathrm{T}_{6}$ shows the best impact on the leaf/plant. At 75 days leaf/plant shows observation $10.60 \%$ increase as compared to the 60days; however the variation in treatment are from 8.33-15.66 and treatment $\mathrm{T}_{6}(30 \%$ sewage sludge $+70 \%$ cocopeat) shows best impact on the leaf/plant. In between treatment, at 15 days $68 \%$ increase in leaf area; At 30days 67.28\% increase; At 45days $48.77 \%$ increase in leaf area; At 60 days $46.32 \%$ increase in leaf area; At 75 days
$33.93 \%$ increase in leaf area respectively. And at 90 days $56.27 \%$ increase in leaf area. At 30days, leaf area observation shows $4.43 \%$ increase as compared to 15days; however the variation in treatments are from 9.80-29.96 square centimeter and treatment $\mathrm{T}_{6}(30 \%$ sewage sludge $+70 \%$ cocopeat $)$ shows best impact on leaf area. At 45 days, leaf area observation shows $10.56 \%$ increase as compared to 30 days; however the variation of leaf area in treatments are from 17.16-33.50 square centimeter and treatment $\mathrm{T}_{6}(30 \%$ sewage sludge $+70 \%$ cocopeat $)$ shows best impact on leaf area. Two part of perlite, one part of date palm and one part of cocopeat showed the good leaf area (Razieh Ebrahimi et al., 2012). At 60 days, leaf area observation shows $36.95 \%$ increase as compared to 45days; however the variation in treatments are from 13.13-24.46 square centimeter and treatment $\mathrm{T}_{6} \quad(30 \%$ sewage sludge $+70 \%$ cocopeat) shows best impact on leaf area. The two part of perlite, part of date palm and one part of cocopeat shows the best impact on the leaf area (Abdolali Hesami et al., 2012). At 75 days, leaf area observation shows $58.69 \%$ increase as compared to 60 days; however the variation in treatments are from 13.43-34.86 square centimeter and treatment $\mathrm{T}_{7}$ (control) shows best impact on leaf area. At 90 days, leaf area observation shows $31.50 \%$ increase as compared to 75 days; however the variation in treatments are from 13.70-31.33 square centimeter and treatment $\mathrm{T}_{6}$ (30\%sewage sludge $+70 \%$ cocopeat) shows best impact on leaf area. It is due to the EC factor when the EC was 
increase $1.0 \mathrm{dS} \mathrm{m}^{-1}$ it increase the leaf area in some cultivar like 'Goha' (Young Hun Lee et al., 2015).

In between treatment, at 15days $62.04 \%$ increase in number of branch/plant; At 30 days $39.75 \%$ increase; At 45 days $53.81 \%$ increase in number of branch/plant; At 60 days $46.18 \%$ increase in number of branch/plant; At 75 days $43.71 \%$ increase in number of branch/plant respectively. And At 90 days $43.71 \%$ increase in number of branch/plant. At 30 days, number of branch/plant observation shows $19.87 \%$ increase as compared to 15 days; however the variation in treatments are from 2-3.32 branches and treatment $\mathrm{T}_{6} \quad(30 \%$ sewage sludge $+70 \%$ cocopeat) shows best impact on number of branch /plant. Some researcher tells that with the high cocopeat ratio result in high chlorophyll $a$ and $b$. it increase the leaf weight and crown in the plants (S. Afsharipoora et al., 2010). At 45 days, number of branch/plant observation shows $23.32 \%$ increase as compared to 30 days; however the variation in treatments are from 2.33-4.33 branches and treatment $\mathrm{T}_{6}$ (30\% sewage sludge $+70 \%$ cocopeat) shows best impact on number of branch /plant. At 75 days, number of branch/plant observation shows $18.76 \%$ increase as compared to 60 days; however the variation in treatments are from 3.33-5.33 branches and treatment $\mathrm{T}_{6}$ (30\% sewage sludge $+70 \%$ cocopeat) shows best impact on number of branch /plant. At 90 days flower/plant observation shows that the $50 \%$ increase as compare to the 75 days; however the variation is from 1.33-2.66 flowers and treatment $\mathrm{T}_{5}(20 \%$ sewage sludge $+80 \%$ cocopeat) shows the best impact on the flower/plant. Some researcher tells that number of flower increase due to increase in perlite using $25 \%$ perlite $+75 \%$ cocopeat (Afsharipoor et al., 2010). At 90 days 50\% increase in the number of fruits/plant as compared the 75 days: however the variation is from 1.33-2.33 fruits and the $\mathrm{T}_{6}$ shows the best impact on the fruits/plant. Some worker worked on the elevation and tells about it depends on where the plants is grown and depends on the root temperature zone. The good quality of fruits is observed at 10 to 30 degree temperature (Masaru et al., 2016). In between the treatment at 90 days, $62.52 \%$ of yield/plant increase. Some researcher (Young Hun Lee et al., 2015) said that the yield depends on the variety also like Albion, the increase yield due to the change $1 \mathrm{EC} 1 \mathrm{dS} \mathrm{m}^{-1}$. But in 'Goha' Varity yield is decrease with increase in the EC. After harvesting the crop the harvesting index shows the $16.01 \%$ change in between the treatment. And the variation is from $0.46-0.55 \mathrm{HI}$ and $\mathrm{T}_{6}(30 \%$ sewage sludge $+70 \%$ cocopeat) shows the largest harvesting index. It is due the sometimes changing in EC from 0.5 to $1 \mathrm{dS}$ $\mathrm{m}^{1}$ (Young Hun Lee et al., 2016).

\section{Acknowledgement}

We are extremely grateful to Department of soil science for providing all facilities related to our analysis work.

\section{References}

Abdolali Hesami, et al., (2012) "Application of Date Palm Petiole (Date-peat) in hydroponics culture of strawberry (Fragaria $x$ ananasa)" Recycling of Organic Waste in Agriculture PP 26-27.

Afsharipoora, S., et al., 2010 "Effect of different planting bed on growth and development of strawberry in hydroponic and aquaponic cultivation system" Plant Eco physiology PP 61-66.

Carine Cocoo, et al., 2010 "Development and fruits yield of strawberry plants and effect by crown diameter and plant at growing periods" PP 730-736.

Douglas, et al., 1975. Hydroponics, 5th ed. Bombay: Oxford UP, 1975. 1-3 
Gowhar, et al., 2013 "Effect of Nitrogen, Phosphorus, and Potassium on growth yield of strawberry.

Kirad, et al., 2009 "Respond of Integrated Nutrient Management in strawberry" ActaHort PP 653-656>

Masaru Sakameta, et al., 2016 "Effect of root temperature on the growth and fruits quality of hydroponically grow strawberry plant" Journal of Agriculture Science vol-8.

Masaru Sakameta, et al., 2016 "Effect of root temperature on the growth and fruits quality of hydroponically grow strawberry plant" Journal of Agriculture Science vol-8.

Patil, N.N., et al., 2013 "Effect of mulching on strawberry production under mid hill condition of Uttarkhand" PP-21-23.

Rakeshkumar, et al., 2013 "Influence of plant growth regulator on growth yield and quality of strawberry" PP 86-91.

Razieh Ebrahimi, et al., 2012. Effect of Different Substrates on Herbaceous Pigments and Chlorophyll Amount of Strawberry in Hydroponic Cultivation System American-Eurasian J. Agric. \& Environ. Sci., 12 (2): 154-158, P

Young Hun Lee, et al., 2015 "Influence of Various Nutrient Concentrations on the Growth and Yield of Summer Strawberry Cultivars Cultivated in a Hydroponic System". Hortic. Environ. Biotechnology. 56(4):421-426.

\section{How to cite this article:}

Vikas, Anjil Kumar, Arun Kumar, Anshu Singh, Praveen Kumar, Jaihoon Rafie, Parkash Verma and Ajay Kumar. 2017. Influence of Different Nutrient Concentration on Strawberry under Hydroponic Cultivation System. Int.J.Curr.Microbiol.App.Sci. 6(10): 2999-3006. doi: https://doi.org/10.20546/ijcmas.2017.610.353 